\title{
Food Crop Diversity and Growth Enhancement Support Scheme a Panacea to Food Security in Nigeria
}

\author{
Aghale, Duke Nduka ${ }^{1 *}$, Umeh, Ogechi. J. ${ }^{2}$ Anyim, Alozie ${ }^{3}$ \\ ${ }^{1}$ Michael Okpara University of Agriculture, Umudike, Nigeria \\ ${ }^{2}$ Michael Okpara University of Agriculture, Umudike, Nigeria \\ ${ }^{3}$ Abia State University, Uturu, Nigeria
}

*Corresponding Author: Aghale, Duke Nduka, Michael Okpara University of Agriculture, Umudike, Nigeria

\begin{abstract}
It has been realized that one of the most pressing problems facing our country is that of immediate increase and diversification of our food supplies in order to sustain the ever increasing population growth at a sufficiently high level of nutrition. As a result of pressure from human activities and economic necessity, many food crops are disappearing from our tables, thus depleting the nation's food resources and contrary to the production of food for local consumption at affordable prices, which has the greatest opportunity on the basis of 'a kobo saved is as good as kobo earned'. Loss of the crop biodiversity has seriously damaged small scale farmer's livelihood despite the growth enhancement support scheme and also drastically reduced the potentials of food sustainability. Recently, out of the 30 cultivated species of food crops that provided $90 \%$ of human calorific food supply in Nigeria, only 15 stands between mankind and starvation. Inculcating food crop diversity in the Growth Enhancement Support Scheme ensures exploitation of more alternatives to maintaining current output of a major crop and simultaneously initiating increase in the production of the alternatives. Diversification will bring about reduction on the dependency of the established food crops hence reducing the current high market prices to affordable price level.
\end{abstract}

Keywords: Food crops, biodiversity, growth enhancement support, food security.

\section{INTRODUCTION}

Diversification is the exploitation of more alternatives to maintaining current output of a major crop but simultaneously initiating increase in the production of the alternatives. When food crops are diversified, there will be a reduction on the dependency of the established food crops hence reducing the current high market prices into affordable price level. The most effective way of actively achieving the food crop diversification with the Growth Enhancement Support (GES) programme is to evaluate, select and encourage value chain addition with greater utilization of crop products that are of local importance which has been termed to be 'poor folk food'. The prices of food crops which has sky rocked in recent times despite the Agricultural Transformation Agenda (ATA) of the past administration is a disappointment for our farmers, policy makers, Scientist, and also a near disaster for all and sundries. Under the ATA programme, the limited numbers of food crops considered to have comparative advantage in area of production within the six geo-political regions are highlighted with the view to enhance them through value addition (Umeh and Nwachukwu, 2015). Therefore, the exclusive dependency on this narrow based food crops even with the value addition, presents a risk of total loss, should any fall victim to disease or weather hazards. The encouragements through the GES to grow the modern improve high yielding crops become unreliable because the idea of growing a narrow range of food crops concentrating the risk to the farmers in this era of climate change.

Food crop diversity and GES under the ATA program is a positive response to the risk of starvation in Nigeria. The diversification process of the food crops must include lesser known indigenous crops from each geo- political zone with an understanding of the crop as food and sources of raw materials. The displacement of these crops by the 'modern crops' have affected the knowledge about the lesser crops which also is forcing them into extinction. 
It is against this backdrop that this work is aimed to x-ray and highlight the need to look inwards and exploit some of the many neglected, endangered, indigenous crops that have served and sustained Nigerians and other Africans for thousands of years for such crops like Acha (Digitariae xilis), Benniseed (Sesanumindicum, L.), Ginger (Zingiber officinale Rosc.), indigenous Millet (Pennisetum typhoideum), Guinea corn (Sorghum bicolor); African nightshade; vegetable amaranth; indigenous bambara nuts; pigeon pea amongst others (FmEnv, 2006). These traditional lesser food crops might be an insurance against food scarcity and hunger in the near future.

\section{OBJECTIVES OF THE STUDY}

The broad objective of the study is to review food crop diversity and growth enhancement support scheme as a panacea to food security in Nigeria. Specifically, the write up will:

i. access food security status of the nation under the Growth Enhancement Support Scheme,

ii. identify indigenous extremely endangered crops species in Nigeria,

iii. propose the imperative need to exploit the adaptive resilient qualities offered by the rich biodiverse indigenous crops/ extremely endangered crops species and

iv. highlight consequences of loss of bio-diversity and declining crop productivity, amidst the global food crisis.

\section{Methodology}

The work is a general review of the nation and strategy used to maximize the land, water and other resources that will provide resource poor farmers with the option of growing different crops with the view of improving farmers' income. The assessment of and process of bringing back crops that have gone into extinction or that have been extremely endangered and creating wider awareness and choice in the production of varieties of crops so as to expand production activities on various food plants.

The nation Nigeria isofficially known as the Federal Republic of Nigeria, is a federal constitutional republic in West Africa, bordering Benin in the west, Chad and Cameroon in the east, and Niger in the north. It comprises 36 states and the Federal Capital Territory, where the capital, Abuja is located, the country is further sub-divided into 774 Local Government Areas (LGAs). Nigeria is officially a democratic secular country (Nigerian Constitution, 2015). With approximately 184 million inhabitants, Nigeria is the most populous country in Africa, accounts for about $18 \%$ of the continent's total population and the seventh most populous country in the world (UNWPP, 2015). The country is viewed as a multinational state, as it is inhabited by over 500 ethnic groups, of which the three largest are the Hausa, Igbo and Yoruba; these ethnic groups speak over 500 different languages, and are identified with wide variety of cultures. The official language is English. Nigeria is divided roughly in half between Christians and Muslims. As of 2015, Nigeria is the world's 20th largest economy, worth more than $\$ 500$ billion and $\$ 1$ trillion in terms of nominal GDP and purchasing power parity respectively (Mwalimu, 2005). Nigeria is located in western Africa on the Gulf of Guinea and has a total area of $923,768 \mathrm{~km}^{2}$ (356,669 sq mi) (WF, 2011), making it the world's 32nd-largest country (after Tanzania). Nigeria lies between latitudes $4^{\circ}$ and $14^{\circ} \mathrm{N}$, and longitudes $2^{\circ}$ and $15^{\circ} \mathrm{E}$. Nigeria is classified as a mixed economy emerging market, and has already reached lower middle income status according to the World Bank (World Bank, 2011), with its abundant supply of natural resources, welldeveloped financial, legal, communications, transport sectors and stock exchange (the Nigerian Stock Exchange), which is the second largest in Africa.

As of 2010, about 30\% of Nigerians are employed in agriculture (NBC, 2010). Agriculture used to be the principal foreign exchange earner of Nigeria. Major crops include beans, sesame, cashew nuts, cassava, cocoa beans, groundnuts, gum arabic, kolanut, maize (corn), melon, millet, palm kernels, palm oil, plantains, rice, rubber, sorghum, soybeans and yams. Cocoa is the leading non-oil foreign exchange earner. Rubber is the second-largest non-oil foreign exchange earner (www.nationsencyclopedia.com).

\section{DISCUSSION}

Access food security status of the nation under the growth enhancement support scheme:

\section{- Food security}


Food security in the basic form is defined as access to the food needed for a healthy life at all time (FAO \& WHO, 1992 in Eide 1999). A country is said to be food secured when majority of her population have access to food of adequate quantity and quality consistent with decent existence at all times (Idachaba, 2004), which implies that food must be available to the people to an extent that will meet some acceptable level of nutritional standards in terms of calorie, protein and minerals needed by the body. Food supply is measured by the mean daily per capita supply of calories while child hunger rate is measured by the percentage of children under age five who are under nourished (UNDP, 1994). Food safety is an intricate and critical art of the sustainable food security. It is the assurance that food products have been handled, processed, packaged, stored, distributed and consumed in a manner that guarantees wholesomeness. As it determines the state of the body, it is the assurance that food consumed will not bring harm to the body. It therefore demands that safety of food be observed along the entire food chain, from production through to consumption. Incidentally, food safety is the aspect of food security that has received the least attention of all the parts of sustainable food security, particularly in developing countries where a combination of poverty and ignorance has confined people to quantity consideration above safety consideration (Chan, 2012). Governments must ensure that foods grown in the country meet safe standard by increased monitoring and supervision through the various agencies concerned to ensure that foods are grown under the safest possible conditions.

\section{- Evaluating Nigeria's food security}

Nigeria was able to feed her citizens in the 40's and 50's with exporting the surpluses. Every region of the six geo-political zones are engaged in the production of two or more major crops and together the country as relatively self - sufficient in food production. The country had groundnut pyramids in the North east, cocoa house in the West, oil palm in the East, rubber in the South- south. The statistics of Food and Agriculture (FAO) show that in 1961, of the 1,706metric tons of shelled groundnut traded in international market reveals that Nigeria exported 502 metric tons translating to $42 \%$ of the entire export. For oil palm, of the 692 metric tons, Nigeria accounted 167 metric tons or 27\%. For cocoa, Nigeria's international trading of 187 thousand metric tons translated to $18 \%$ while Nigeria exported 49,000 metric tons of the 3.755 millon metric tons or $1.4 \%$ of cotton in the global market (Food Security Magazine, vol.3 no. 6) But the agricultural sector receded to the backseat and we began to lose our bearing as we fostered an import- dependent economy to the detriment of the deepening of the productive base of our economy through agriculture inspired industrialization and economic boom. The astronomical rise in the prices of food items occasioned by the discovery of oil, a whopping \$2billion are needed to import about six million tons of wheat, $\$ 750$ million on rice, $\$ 700$ million on milk and other dairy products. Beyond the high prices of staple food in Nigeria, drought and political situation seems to pose a threat on our food supplies. It is instructive to note that Nigeria requires about 2.5 million tons of rice annually while local rice production is less than half a million tons per year. The enormous resources that should have gone into addressing the country's development needs, citizens' growth index and the nation's food security are turned into capital flight to other nations. Against this backdrop that the Growth Enhancement Support scheme was embarked upon and under the scheme, poor farmers who are captured in the validated data base were provided with farm inputs (seeds), fertilizers and seedlings. The scheme was design to break the inefficient input support delivery to farmers, eliminate spurious farmers and ensure that the nation's huge investment reaches target beneficiaries which are the real farmers (Nigerian Agric Digest, 2012). The Growth Enhancement Support scheme (GES) targets five million smallholder farmers annually with a target of 20 million farmers over the next few years and this will encourage increase input leading to increase yield that guarantees food security with attendance plan to enhance the national yield of tubers and cereals by incremental 600,000 metric tons per annum ((Nigerian Agric Digest, 2012). It is therefore expected that adhering to the ideals of GES, our nation is expected to pave way for a deepening of the productive base of our economy through an agriculture inspired industrialization and economic boom. If this had happened, we may confidently proclaim that truly the small scale rural farmers are receiving recognition and can be hopeful that Nigerian's agriculture is on the path of true restoration.

\section{- Food insecurity in Nigeria}

It is known that availability of food alone does not seem sufficient to explain the attainment of food security in a country, since food can be available due to effective agricultural policy, good harvest in a 
particular season or massive food import particularly by developing nations. The negative effect is usually on the foreign reserves which causes budgetary hemorrhage on the country (Davies, 2009). Adeoti, (1989) reported that food insecurity is lack of access to enough food which arises from lack of resources to produce or acquire food. In essence a country should be considered as food secure when food is not only available in the quantity needed by the population consistent with decent living but also when the consumption of the food should not pose any health hazard to the citizens. Food security should not be seen from the perspective of availability but hygiene and safety is also given important consideration in order to protect the health of the people. Food may be available but the source from which the food is produce or processed may be unhygienic or that the chemical substances used in its production, processing or preservation may constitute a health hazard. The improper application of the right type, quality and quantity of inputs, particularly insecticides, herbicides and fertilizer since most of these inputs are not just dangerous to the growing plant or animal, but leaves toxic residue on the final food products.

The national and international concern regarding the food shortage has resulted into fighting hard to ensure increase in food production by the use of pesticides. The aim being to fight the enemies of crops and at the same time increase agricultural output at the detriment of food safety.Pesticides as we know are chemical substances which will particularly kill pest when applied in correct form and on appropriate crops or animals. It is right to say that about half of the world food supply is still lost due to the activities of crop pest, diseases, and weed. And the dramatic increase in agricultural efficiency that has occurred in develop countries was achieved in part because of development in crop protection technology and particularly the advent of pesticides. But, the complexity and speed of change in modern crop protection has created a need for caution on the use and application of these synthetic chemical pesticides which has resulted in food insecurity. In Africa, Caribbean, and Pacific (ACP) countries indiscriminate use and abuse of pesticides have resulted in many forms of human diseases and crop failure. For example, the use and application of DDT to eradicate Tsetse flies has proved to be dangerous to human health because studies in Zimbabewe as well as samples previously tasted by World Health Organization (WHO) showed human milk to be twice as contaminated with DDT(Pest Management and Food Production, 1995). Wrong use and applications of these pesticides have resulted in environmental pollution, water pollution damage to our farmlands, crop failure and other human maladies.

\section{Identify indigenous extremely endangered crops species in south eastern Nigeria:}

Nigeria is rich in plant genetic resources which exist in wild forms in the plants' natural habitats and in diverse crop landraces/ecotypes/cultivars. The extent of direct and indirect dependence on plants is high in Nigeria because for the majority of the population living in the rural areas, daily energy requirement is almost entirely from plant sources. Plants are used as food, spices/condiments, herbs, energy source and raw materials.

- List of some uncultivated plants with food and agriculture potentials in Nigeria with their Common names and relative importance (food security, economic \& social)

\begin{abstract}
Botanical name
Aframomummelegueta
\end{abstract}

Afzeliaafricana

Artocarpuscommuni

Blighiasapida

Brachystigiaspp

Canariumschivenfuttii

Chrysophyllumalbidum

Cola gigantean

International Journal of Advanced Research in Botany (IJARB)

\section{Common name}

Alligator pepper

Akpalata

Breadfruit

Akee-apple

Achi

Ube; Okpoko

African star appleAgbalumo

(yoruba)

Ebenebe
Uses

Seed used as spice in conjunction with kola; also used in ritual observance; forest/savanna

Seed used as condiment for thickening soup; leaves used as fermented vegetables.Savanna plant.

Big seedless edible fruit eaten like yam.

Seed and edible, forest plant.

Seeds used as condiment for thickening soup. Forest plant.

Fruit eaten; source of fat, oil veneer plywood, forest plant

Fruit pulp edible and good for jam; forest plant.

Seeds used as condiment for 


\begin{tabular}{|c|c|c|}
\hline Cola pachycarpa & Achicha & $\begin{array}{l}\text { thickening soup, savanna plant. } \\
\text { Testa eaten fresh ; forest plant. }\end{array}$ \\
\hline Cola lepidota & Achicha & Testa eaten fresh ; forest plant \\
\hline Dacryodesedulis & African pear & $\begin{array}{l}\text { Fruits eaten with maize; source of } \\
\text { oil \& fat; kernel suitable for animal } \\
\text { feed formulation;forest plant. }\end{array}$ \\
\hline Dennettiatripetala & Nmimi (Igbo) & $\begin{array}{l}\text { Fruit eaten fresh; served as } \\
\text { kola;useful for insecticide } \\
\text { preparation; forest plant. }\end{array}$ \\
\hline Detariumspp & Ofo & $\begin{array}{l}\text { Seeds used as condiment for } \\
\text { thickening soup, similar to ogbono; } \\
\text { savanna plant. }\end{array}$ \\
\hline Dialiumguineanse & Velvet tamarind Awin (yoruba) & $\begin{array}{l}\text { Seed eaten fresh; very good source } \\
\text { vitamin C; suitable for fruit drink } \\
\text { and jelly; savanna and forest plant. }\end{array}$ \\
\hline Garcinia kola & Bitter kola & $\begin{array}{l}\text { Seeds eaten fresh; served as kola; } \\
\text { high medicinal value; reputed } \\
\text { snake repellant; forest plant. }\end{array}$ \\
\hline Garciniapolyantha & Bitter kola & $\begin{array}{l}\text { Seed edible and eaten fresh; forest } \\
\text { plant. }\end{array}$ \\
\hline Hidegardiabarteri & Ufuku (Ibo) & $\begin{array}{l}\text { Seeds used as condiment for } \\
\text { thickening soup; stem bark use as } \\
\text { fiber; forest and savanna plant. }\end{array}$ \\
\hline Irvingiagabonensisvar & Excels & $\begin{array}{l}\text { African mango Fruit pulp eaten; } \\
\text { suitable for fruit drink and jam; } \\
\text { kernel used as ogbono in } \\
\text { thickeningsoup; kernel as ogbono; } \\
\text { forest plant. }\end{array}$ \\
\hline Tamarindusindica & Tamarind & $\begin{array}{l}\text { Fruit pulp eaten fresh; suitable for } \\
\text { fruit drink and garnish for } \\
\text { fish.Savanna plant. }\end{array}$ \\
\hline Tetracarpidiumconophorum & Walnuts & $\begin{array}{l}\text { Seeds edible; very high in protein; } \\
\text { source of conophor oil (drying oil); } \\
\text { forest plant. }\end{array}$ \\
\hline Tetrapleuratetraptera & Ushakirisha (Ibo); & $\begin{array}{l}\text { Seeds used as spice for flavouring } \\
\text { yam pottage; fruits used } \\
\text { medicinally; forest plant. }\end{array}$ \\
\hline Treculiaafricana & African breadfruit & $\begin{array}{l}\text { Nuts boiled as beans or rice roasted } \\
\text { as in groundnut; suitable for bread; } \\
\text { biscuits and cake; leaves and fruits } \\
\text { pulp good as browse and fodder; } \\
\text { forest plant. }\end{array}$ \\
\hline Lendolphisoweriensis & Utu (Ibo); Panukuru (yoruba) & $\begin{array}{l}\text { Fruits eaten fresh; suitable for jam } \\
\text { and jelly; forest plant. }\end{array}$ \\
\hline Kondiawhitei & Adoo & $\begin{array}{l}\text { Fruits edible eaten fresh; served as } \\
\text { kola; forest plant. }\end{array}$ \\
\hline $\begin{array}{l}\text { Monodoramyristica } \\
\text { Uvariachama }\end{array}$ & African nutmeg & $\begin{array}{l}\text { Seeds used as spice; forest plant. } \\
\text { Ripe fruit pulp is eaten; the plant is } \\
\text { a re-growth shrub in forest }\end{array}$ \\
\hline Piper guineense & Uziza & $\begin{array}{l}\text { Dried black berries and the red; } \\
\text { fresh fruit are used in flavouring } \\
\text { foods; it is a forest scardent- } \\
\text { climbing plant. }\end{array}$ \\
\hline
\end{tabular}

Food plant diversity is a strategy to maximize the use of resources and give wider choice in the production of a variety of crops in a given area so as to expand production activities on various crops. It is a means of bringing back crops that have gone into extinction such as indigo, Sphenostylisstenocarpa Harms (Odudu), Plukenetiaconophora Mull Avg (ukpa), Landolphlaowariensis P.Beauv (utu), DenettiatripetalaG.Bak (Mmimim), Canariumschweinfurhii ( agbska) CpoulaedulisBaill ( Udi).

Agriculture is strategic to the Nigerian economy and plays the key roles of supplying food for the population, rawmaterials for industries, earning high foreign exchange which is next only to that from 
crude oil, providing market for the industrial sector and a key contributor to wealth creation and poverty alleviation. The diversity of both the major and minor Nigerian crops is decreasing because the rate at which the diversity is lost due to habitat destruction and over-exploitation is far more than the rate at which collection and conservation are done.

There are 7,895 plant species (from 338 families and 2215 genera that have been identified in Nigeria (FmEnv,2006). About 0.4 and $8.5 \%$ of the plant species are considered threatened and endangered, respectively. Of the IUCN list of threatened species, 146 are found in Nigeria, 18 under the 'endangered' and 15 under the 'critically endangered' categories (FmEnv, 2006).

Recently, out of the 30 cultivated species of food crops that provided $90 \%$ of human calorific food supply in Nigeria, only 15 stands between mankind and starvation. The loss of the crop biodiversity has seriously damaged small scale farmer's livelihood despite the growth enhancement support scheme and also drastically reduced the potentials of food sustainability. The fear is that many of the useful indigenous/wild species could disappear - leaving rural communities less resilient and vulnerable to hunger and poverty. Thus knowledge of these plants and the plants are fast disappearing due to:

1. Wanton deforestation by human and natural causes.

2. Ageing and dying farming population that is familiar with the traditional landraces of different crops.

3. Neglect of farming by the youths and village to urban drift, leading to drastically reduced crop farming and disappearance of landraces that require regular annual cultivation.

4. Adoption of crop monoculture of improved cultivars that completely relegates landraces and therefore leads to their disappearance.

5. Inadequate records and storage of seeds of released improved cultivars by relevant government institutions and effective extension services to ensure the adoption of these cultivars alongside the landraces.

6. Lack of expertise and adequate funding for plant genetic resources collection, characterization/evaluation and conservation.

In view of these problems the exploration, collection and conservation of some threatened plant genetic resources including wild relatives of some cultivated crops needs urgent attention through national and international collaborative initiatives on genetic bank projects.

\section{The need to exploit the adaptive resilient qualities offered by the rich bio- diverse indigenous crops/ extremely endangered crops species for food diversity.}

There is no gain saying that modern farming system has marginalized our traditional food crops due to the perceived rewards, but the well-known respect for the lesser traditional crops are lost and many people are starving to death as a result of over dependency on the very few modern crops. Farmers no longer have knowledge of the old traditional lesser crops which they fall back onto in time of food scarcity neither do the few persons who are the traditional custodian of their knowledge alive to pass same in order to save the extinction of these valuable crops.

Diversity as response to risk of starvation is one of the benefits that must be practiced towards ensuring food security in Nigeria. The diversification of food crops which must include the lesser known indigenous plants with the understanding of their ecology will motivate our resource poor farmers to produce these crops with the assurance that there will be market for them. It will no longer be enough to encourage its production; rather other complementary measures such as increase storage capacity, improved market system and input availability must be taken into consideration.

The government intervention in the area of endangered food crop production is to produce clean and high disease - free lesser food crops with high yield that will improve the income of the rural farmers and ensure environmental and social sustainability of such crops based on production systems. The Growth Enhancement Support (GES) scheme which is currently being applied in the production of these limited but preferred food crops that has helped in rehabilitating the farms, making them national champion should be extended to the production of endangered lesser crops (Kalu, 2013). Although, Nigeria accounts for about $2 \%$ of the world's tuber food crop production, the government 
effort to increase production in other crops are being hampered by old and unproductive farming implements, poor infrastructure, pests, diseases, low farmers education and inadequate supply of farm inputs among others.

The federal government of Nigeria in2012, inaugurated the GES scheme to promote food crop production through the design and implementation of programs involving new planting and rehabilitation of old plantations, with the overall objectives of increasing food production substantially and in its quality. Adesina, (2012) reported that the thrust of the intervention is to increase food production of the very few over dependent crops to 20 million metric ton with less regards to the endangered and extremely endangered food crops.

Perhaps, the time has come through the Agricultural Transformation Agenda and Growth Enhancement Support scheme to embark on the potentials of many other food crops that could be used as staple crops with the diversification of these lesser crops that shall usher in a reduction on the dependency of the already over established few crops with its attendant high prices

Be that as it may, lesser known crops are used in the rural areas but more information about them is needed from the few farmers that will cultivate them so as to determine how to process, preserve and store them for value addition. These unfamiliar food crops when properly identified require further steps to add value for its economic importance. Hence, it will no longer be enough to encourage their production, but other complimentary measures be considered in other to increase and improve their market potentials.

\section{Consequences of loss of bio-diversity and declining crop productivity, amidst the global food crisis.}

The prices of food crops which have skyrocketed in recent times as a result of our narrow base is a disappointment for our farmers and the time has come for us to embark on the potentials of many other food crops that could be used as stale food. Diversity as a response to risk of starvation should be practiced and channeled more towards extremely endangered species that are sources of food, pharmaceutical or industrial products. For example, about $25 \%$ of medicines are of direct plant origin and this percentage will rise up to 50\% if one takes into account products which have been only slightly modified to improve on the natural plants, and yet it is estimated that only about $2 \%$ of potentially useful medicinal plants have so far been discovered.

The exclusive dependant on the limited number of food crops presents a risk of total loss when any fall victim to diseases like in the case of tomato and maize in Nigeria this year (2016) or weather hazards. This was also the case In 1979, when there was an outbreak of cassava mealy bug which nearly ravaged the whole of South Eastern states of Nigeria that gave rise to the recurrent age - old killer (hunger) that struck the entire population. The result of pressure from human activities and economic necessity had made it possible for most food crops to disappear in our states which are contrary to the production of food for local consumption at affordable prices.

\section{CONCLUSiON}

Lesser known food crops which have been extremely endangered were used in most rural communities to caution hunger in the years gone and therefore must be embarked upon for a better economic utilization for food security. The information needed about them should be gotten from the few farmers that once cultivate them which will assist to determine on how to process, preserve and store them for further value addition. These unfamiliar food crops when properly articulated and identified required further awareness from the extension experts to disseminate information about their economic importance. Hence these lesser endangered crops might be an insurance against food scarcity and hunger in the near future.

Therefore, at a point of identifying some of these lesser crops, the government and policy makers should borrow a leaf from Frederick the Great who in 1756, stopped potato from going into extinction by decreeing that all his subjects must plant potato when starvation struck the Europeans states despite their believe that potato causes leprosy, syphilis and meant for second class citizens of the Irish people. Today, the greatest per capita consumers of potatoes are the Europeans since it has revolutionized their eating habit. The traditional food crop diversification can be safeguarded with assurance of food for all in the near future. 


\section{REFERENCES}

Abuja. Country report on the state of plant genetic resources for food and agriculture.

Adesina, A (2012). Agricultural Transformation Agenda (ATA) update.In Nigerian Agric Digest Vol.3 No. 2

Babatola, J. O. and Adelaja, B. A., (1999). Indigenous and Lesser exploited fruit trees for thenew millennium in Nigeria In: Genetic and food security in Nigeria in the twenty-first century. Ed

Chan, M. (2012).Food safety in food security magazine, vol .3 No.6 Pp 12-13.

Fmenv, (2006).National Biodiversity Strategy and Action Plan, Federal ministry of Environment,

Olaoye, G and Ladipo, D. O. (1995).Pest Management and Food Production.Genetics Society ofNigeria.Pp.99-108. In Food, Agric\& Environment Discussion paper 25.

Umeh, O. J and Nwacukwu, I. (2015).Revamping Grassroots Agricultural Production through the Agricultural Extension Transformation Agenda.In Contemporary Issues in Extension System and Development. Nwachukwu, I. (eds). Pp 1-13.

Citation: D. N. Aghale et al. , "Food Crop Diversity and Growth Enhancement Support Scheme a Panacea to Food Security in Nigeria ", International Journal of Advanced Research in Botany, vol. 3, no. 4, p. 16-23, 2017. http://dx.doi.org/10.20431/2455-4316.0304003

Copyright: () 2017 Authors. This is an open-access article distributed under the terms of the Creative Commons Attribution License, which permits unrestricted use, distribution, and reproduction in any medium, provided the original author and source are credited. 